\title{
The policy objectives of the injunction and compliance order provisions in the Labour Relations Act 1987
}

\author{
Graeme Buchanan*
}

\section{Introduction}

I am asked to discuss policy objectives, so let me first both limit and clarify my credentials to do so. I do not represent the Minister of Labour or his policy advisors, nor are any views I express necessarily those of my employer, the Department of Labour. So I do not write with the authority of a policy maker.

Rather I write as a lawyer who provided some advice to the policy makers during the exercise that led to the passage of the Labour Relations Act in 1987. In broad terms I was advising them on how to achieve their stated policy objectives. In practice this can require some involvement in the policy-making process itself, because often broad policy objectives can only be achieved after second-tier or lower level policy issues have been identified and worked through. So, coming from that background of involvement in that process I can perhaps offer you some informed comments on the provisions concerned, but not necessarily authoritative ones.

I note that the title of this seminar, "Strikes and the Labour Court", would seem to limit my discussion to the intended impact of the injunction and compliance order provisions on industrial action. The compliance order jurisdiction does however cover a far broader area than strikes (or lockouts). To fully address and appreciate the objectives behind that jurisdiction it would be necessary to go beyond the narrow but topical issue of strike action and mention the wider concept of compliance with the Act, and awards and agreements, generally.

More importantly, I would suggest that the aim of the compliance and injunction provisions cannot be properly ascertained simply by looking at them in isolation. Their role in the total scheme of the Act, in particular their relationship to dispute-solving mechanisms and sanctity of agreement, must be assessed, as must the direct impact on them of the Labour Court's changed jurisdiction and structure. But before adopting my own suggestion and looking at these provisions in the wider context, I think it may be helpful to give a preliminary brief explanation of the injunction and compliance order provisions in a narrow sense. 


\section{The narrow perspective}

\section{Injunctions:}

When I talk about the "injunction provisions" of the Act I am referring not only to section 243 , which expressly deals with injunctions, but also to section 242 , dealing with the tortious jurisdiction. Clearly, one remedy sought in the course of such tortious actions may well be an injunction.

Sections 242 and 243 represent Parliament's attempt at transferring a specific and limited area of the High Court's jurisdiction into the new Labour Court's jurisdiction. It was a simple change of venue, with virtually no attempt to change the rules by which the game was to be played (see s.279 (4) and s.303 (1), but note s.242 (3) and s.243 (3)). The intention was for the specialist labour relations Court to bring its expertise to bear also on these particular labour relations matters, but applying the same law that had always been applied. That approach accords with the strong sentiments expressed by the Court of Appeal in 1985 in the Irvines Bakery ${ }^{1}$ case to the effect that it was desirable that industrial issues be dealt with in the first instance by the Arbitration Court. Parliament would seem in this regard anyway to have converted that desirability into an imperative.

\section{Compliance orders}

As pointed out in the Irvines Bakery case, the old Arbitration Court had within its armoury the power to issue compliance with any award, order or collective agreement (s. 48 (2) (d) of the Industrial Relations Act 1973). The effectiveness of that power was questionable, however, given that recourse had later to be had to the ordinary courts to ensure compliance with the so-called compliance order. The Arbitration Court seldom, if ever, used the power. Section 207 of the Labour Relations Act gives a new life and emphasis to this power. It extends the power to breaches of the Act itself and to breaches of orders of bodies constituted under the Act. It gives the District Court a similar power in matters under the Labour Relations Act. It makes it clear that a compliance order may be the sole remedy sought in any case or it may be an ancillary remedy. Finally, it gives the Court itself effective powers to ensure that the compliance order is complied with. The objectives of this rejuvenated compliance order procedure were twofold. Firstly, to give the Labour Court itself a simple yet effective way of finalising matters. Secondly, to give applicants to the Court a straightforward means of obtaining effective remedies for breaches which affect them.

\section{The Act as a whole}

As I have said, the compliance order and injunction provisions need to be viewed in the wider context of the new system established under the Labour Relations Act if we are to appreciate what Government hoped to achieve from them. The long title to the Act professes it to be an Act "to provide procedures for the orderly conduct of relations between workers and employers". One of the main thrusts of the Act is in fact to make it clear that in an industrial sense it is up to the parties to determine their own destinies. 
The Government's White Paper of September 1986 saw collective employment documents being in future "freely negotiated, administered, and enforced by the parties."

This self-enforcement aspect of the Act had been discretely foreshadowed by the practice of the Minister of Labour since he took office in 1984. In marked contrast to his predecessors he had remained aloof from industrial disputes, earning rebukes and a nickname for doing so, but certainly establishing new precedents in New Zealand's industrial relations scene. The consistency of the stance seemed to heighten the accuracy, yet dismiss the implicit criticism of the nickname. The 1987 Act provided an even better scenario for such a stance to thrive in. Statutory penalties were removed from the legislation. The role of the Department of Labour was significantly reduced. The industrial parties or players were given clear rules as to what was and was not possible, and clearly applicable mechanisms for resolving disputes were put in place, with suitable institutions to back them up.

The most significant of those institutions is of course the one of last resort, the Labour Court. Under the 1973 Industrial Relations Act, it had been clearly acknowledged by the ordinary courts that the Arbitration Court had a special interest and expertise in industrial issues - an interest and expertise that ought not to be preempted if it could be avoided. Yet it was undeniable that there was overlapping jurisdiction in some areas, so that a choice of the type of action to be taken determined which court the matter was to be argued in. This had several undesirable features, not the least of which was that at the end of the day, having utilised extensive resources to argue a case in the ordinary courts, the parties might find themselves referred back to the specialist court. The 1987 Act aims to concentrate disputes in the Labour Court - hence the transfer of the tort and injunction jurisdictions, and importantly the transfer of the relevant aspects of the High Court's judicial review jurisdiction (s. 280).

The Court itself is not only given additional judicial jurisdiction. It is stripped of the previous arbitral and registration functions so that it truly becomes a Court, concerned only with judicial matters. It is streamlined so that it becomes largely a judge-only Court, with only limited instances where lay personnel need sit on it. It is, independently of the statute, decentralised, so that it will have permanent courts based in Auckland and Christchurch as well as Wellington. In addition it is given by section 307 the power to make rules regulating its practice and procedure, which, significantly in the injunction area, gives it scope for reducing the procedural constraints that were inherent in the High Court jurisdiction. Urgency is also expressly provided for (s. 296). All of this adds up to a clear statement of support for a court which is to be a specialist in its area, which is to be able to both grant hearings and give decisions quickly when necessary, and which has the procedural ability to get straight to the heart of matters. In this institutional context the injunction and compliance order provisions become practical and sensible propositions in the appropriate circumstances.

Sanctity of agreement is the next issue of relevance. When moving the Second Reading of the Labour Relations Bill in the House last year, the Minister of Labour predicted that the provisions of Part VII "coupled with the powers of the Labour Court to order compliance, will greatly strengthen sanctity of agreement". Part VII of the Act enacts a bargaining system that emphasises a single enforceable end-product. Each worker is covered by one enforceable award or agreement that, subject to the new matters and redundancy provisions, cannot be altered during its currency. The award exemption process (s. 152) and the limited availability of the registration process provide disincentives to attempts at overriding such awards or agreements. Add to this an arguably clearer distinction between disputes of interest and disputes of rights, and appropriate mechanisms for resolving such disputes, and you have in New Zealand terms an 
unprecedented emphasis on sanctity of industrial accords. The compliance order provisions (and to a lesser extent the injunction provisions) are merely the icing on the cake in this respect.

Accepting that sanctity is an ideal, industrial disputes and industrial action are realities that have to be legislated for rather than legislated against. The Government recognised this by putting in place a system that firstly provides appropriate dispute-resolution procedures (e.g. conciliation, dispute committees, grievance committees, the Commission and the Court), that secondly exerts subtle pressures on the parties to play by the rules (e.g. s.152, s. 189 , s. 218), and that finally accepts the inevitability of industrial action but which classifies it as lawful or unlawful depending upon whether or not there exist other means of resolving it which should have been followed. Such classification only really becomes significant in the context of tortious or injunction proceedings. Where industrial action can be classified as lawful then sections 233 (2), 242(3) and 243 (3) make it clear that the Labour Court has to dismiss any tortious or injunction action if it resulted from that lawful strike or lockout. If my understanding of the common law is correct this has an impact only on conspiracy actions, where lawful actions may still have been actionable if the predominant purpose was to injure the plaintiff.

One of Government's stated objectives was to establish a clearer definition of the circumstances in which strikes and lockouts are lawful or unlawful (White Paper, 1986). This is a different proposition from attempting to establish whether or not strikes and lockouts are actionable or not. Although declaring a certain type of strike or lockout to be lawful may preclude successful tortious or injunction proceedings in respect of it, there may well be situations where compliance order proceedings are possible, even though the strike or lockout in question is, in terms of the Act, prima facie lawful. An example might be where the applicable award contained a clause by which the workers agreed not to strike in respect of a dispute of interest during the currency of the award. In such a case a strike relating to a dispute of interest one week before the expiry of the award is, in terms of s.233 of the Act, lawful. But it would also constitute an apparent breach of the current award and as such give rise to the possibility of an action for a compliance order.

You will note that the Government's stated intention was not to try to classify every type of strike or lockout as lawful or unlawful. Sections 233 and 234 clearly do not describe every situation in which a strike or lockout may occur. It is easy to think of other situations which are not covered - sympathy strikes or political strikes for example - and the Labour Court has already had at least one case before it where the strike was held not to be of a type described in either section 233 or section 234 (Hancock's case ${ }^{2}$ where Chief Judge Horn found that the strike concerned an overall ongoing disruptive situation in the workplace and the basis for it was far wider than a particular personal grievance).

Still addressing the wider context into which the compliance order and injunction provisions fit, I return to some matters I have mentioned in passing already. The first is the removal of statutory penalties from the legislation in respect of strikes and lockouts. Such penalties had proved themselves to be singularly inapt and ineffective for preventing or solving disputes. The State, through the Department of Labour, became the meat in the industrial sandwich. It was no-win country - pressure to take action, pressure not to take action, presssure to stop taking action, the last often exerted by an unholy alliance between the parties after they had resolved their differences. The new labour relations 
system looks to the parties to resolve their differences using certain defined procedures, which they themselves must initiate. It recognises that this will not always work, so, as the White Paper says, it strengthens their ability to protect their own rights. This strengthening is most evident in the revamped compliance order procedure, but is assisted by the enhancement of the status of the Labour Court and the transfer to it of certain former High Court jurisdictions.

Another matter already touched upon is the reduction of the role of the Department of Labour. Departmental Inspectors previously had a significant role collecting wage arrears and taking actions for breach of award. This was in addition to their role of taking either penalty or prosecution action for breach of the legislation. The tendency was therefore for the parties to be at arm's length, with contact often effectively through the Department, not as intermediary but as enforcer for one side or the other. Putting aside the question of the appropriateness of that role, one thing was clear - enforcement by fine or penalty was more, often than not, only a nuisance, with continued non-compliance often following the payment of the fine or penalty. Clearly if there were to be binding agreements between parties the objective had to be to ensure that commitments under those agreements were met. It benefited the one party little to see the other party punished monetarily for ignoring commitments if that other party continued blithely to ignore them even after punishment. What was needed was an effective and useful remedy.

What seemed most useful was compelling the other party to comply with their existing legal obligations. Hence the emphasis on expanding the compliance order jurisdiction. It is akin to the contractual remedy of specific performance, but without the restrictive overlay of rules that limit the availability of that remedy. It recognises that the aggrieved party is not necessarily interested in seeing the other party penalised but rather in seeing them do what they are supposed to be doing anyway. If damages or a monetary penalty are also seen as appropriate then tortious remedies or a penalty action are available also. But it is a matter for the aggrieved party to determine in all the circumstances. More often that not, having the other party punished in some way will sour rather than improve the relationship between the parties.

It is to be noted that the compliance order jurisdiction is a discretionary one (recognised by Chief Judge Horn in the Hancock's case). It is also tempered by the Court's special equity and good conscience jurisdiction. This is an implicit indication that compliance orders were not seen to be available as a matter of right simply on proof of breach. There may be other relevant factors, importantly, the availability or otherwise of other appropriate procedures to resolve the dispute. It would seem unlikely for example that the compliance order jurisdiction could be used to circumvent the disputes committee or grievance committee process, but it may of course be used to reinforce both the use of such a process and its result.

It may also be used to prevent a disputes procedure being invoked inappropriately. In the Fortex ${ }^{3}$ case, Judge Palmer had to consider whether the subject matter of the proposed compliance order was properly within the definition of a dispute of rights. In granting the compliance order sought, he made an interesting statement at page 15 which I think is important to the relationship between the compliance order jurisdiction and other disputeresolution procedures under the Act. He said this: 
A dispute of rights cannot be created ... because one party to an agreement elects to misconstrue its application, purpose and scope ... I am not prepared to elevate the company's plain misconstruction to a dispute of rights.

Judge Palmer's decision in that case, in my view serves to confirm that the new system provides clearly applicable mechanisms for resolving certain defined types of dispute and that where those mechanisms do not apply and a breach is established the discretion to issue a compliance order will be exercised positively.

\section{Effective remedies}

I have suggested that one intention of the new system was to provide effective remedies. How was this intention evidenced in the Labour Relations Act? As far as injunctions were concerned there seemed no doubt that the remedy, to the extent that it had been sought in the past, was an effective one. Hence the straight transfer of the tortious and injunction jurisdictions from the High Court without any real substantive change. Similarly there was no tinkering with the interim order jurisdiction linked to the transfer of judicial review from the High Court.

The compliance order jurisdiction was another matter. Obviously the provision in the 1973 Act was less than adequate. The starting point was the scope of the jurisdiction. To provide the parties with an effective remedy, but only in certain areas of their activities, would have been only doing half the job. Accordingly the availability of the compliance order had to be universal in matters involving the Labour Relations Act. Hence the detail of section 207 (1) (a) and (b) and also the ability of the District Court to utilize the jurisdiction.

The type of proceedings required were another question. To place as few procedural restrictions as possible in the way of applicants was the aim. Hence, we have section 207 (2) and (3) which provide that the compliance order may be sought as the sole remedy, as an ancillary or substituted remedy, or may be imposed by the Court even where not sought. Flexibility was provided by subsections (4), (5) and (6) to the extent that orders can be conditional and can be of an interim nature to allow the party in breach to avoid some additional order of the Court. Most importantly, section 207 (7) gives the Court itself significant powers where a compliance order is not adhered to. It is no longer necessary to seek further enforcement via the inherent contempt jurisdiction of the High Court.

\section{Summary}

I have suggested that the proper perspective of the injunction and compliance order provisions is provided by looking at them in terms of their contribution to an entire and new labour relations system. The need for more effective and available enforcement mechanisms is heightened by the removal to a large extent of the state from the arena. The parties, when left to their own devices, must be able to police their own agreements effectively. If sanctity of agreement is to be an achievable ideal then, once all the inducements have been ignored, there must be an effective enforcement backup. Where enforcement has to occur through a judicial process, the Court involved must have sufficient standing and expertise and possess effective powers. Effectiveness in the labour relations arena is not necessarily provided by punishment. The ideal is that obligations be met. 
Whether these sort of ideals and objectives have been met is something that time will tell. John Hughes and Gordon Anderson provide an analysis of the Labour Court's decisions in the area to date (Hughes and Anderson, 1988). Perhaps that analysis will enable you to judge for yourselves. The only assessment I can offer you is a very superficial and general one and it is this: That the Court itself seems, with respect, to have quickly come to terms with these new roles and to be giving decisions that are in the main consistent and that accord with the objects and provisions of the Act. That the parties, on the other hand, have been quick to use the new jurisdictions but slow to appreciate when it is appropriate to use them. I think that with time the whole system will be better understood by the participants and from that will follow a decreasing readiness and need to reach for a Statement of Claim.

\section{References}

Hughes J and Anderson, G (1988) Injunctions and compliance orders: an analysis of theLabour Court's powers and decisions New Zealand journal of industrial relations 12(1): 49-62.

White Paper (1986) Goverment policy statement on labour relations Wellington, Government Printer.

\section{List of cases}

Hancock and Company v Wellington District Hotel ,Hospital, Restaurant, etc. IUW and others unreported, Labour Court, 2 October 1987, LC 9/87.

New Zealand Baking Trades Employees IUW v General Foods Corporation (NZ) Ltd [1985] 2 NZLLR 110.

New Zealand Meat Processors etc. IUW v. Fortex Group Ltd., unreported, Labour Court, 20 November 1987, LC 53/87. 
The Journal of the Industrial Relations Society of Australia

Editor: Professor John Niland, The University of New South Wales

December 1987 - Volume 29 Number 4

\section{Articles}

New Right or Old Wrong? Ideology and Industrial Relations Braham Dabscheck

Productivity, Negotiation and Arbitration: The Coal Industry Case, 1985-86

Greg Smith

Access of Different Socio-Economic Groups to Trades in Australia Denis Davis

Multi-Employer Cohesion in Australian Construction

Joseph B. Rose

Models of National Employer Co-ordination, 1890-1980

David H. Plowman

Psychological Aspects of Redundancy: An Australian Case Study

Peter J. Dowling, Helen De Cieri, Gerard Griffin and Michelle Brown

The Early Uses of the Industrial Relations Concept

Richard Morris

The Robe River Affair

A.C. Copeman

The Arbitration Commission-Should It Be Preserved?

John Moore

Book reviews

Published quarterly. Subscription: Australia $\$ 32$, overseas $\$ A 45$ (surface mail).

Single issues: \$A9 (including postage). Order from the

Business Manager, The Journal of Industrial Relations,

GPO Box 4479, Sydney, NSW 2001, Australia. 